Elsevier required licence: (C) <2019>. This manuscript version is made available under the CC-BY-NCND 4.0 license http://creativecommons.org/licenses/by-nc-nd/4.0/

The definitive publisher version is available online at

[https://www.sciencedirect.com/science/article/pii/S0048969719313841?via\%3Dihub] 


\section{Insight into greenhouse gases emissions from the two popular treatment technologies in municipal wastewater treatment processes}

Thi Kieu Loan Nguyen ${ }^{\mathrm{a}}$, Huu Hao Ngo, ${ }^{\mathrm{a}, \mathrm{b},}$, Wenshan Guo ${ }^{\mathrm{a}, \mathrm{b}}$, Soon Woong Chang ${ }^{\mathrm{c}}$, Dinh Duc Nguyen $^{\mathrm{c}, \mathrm{d}}$, Long Duc Nghiem ${ }^{\mathrm{a}}$, Yiwen Liu ${ }^{\mathrm{a}}$, Bingjie Ni ${ }^{\mathrm{a}}$, Faisal I. Hai ${ }^{\mathrm{e}}$

${ }^{a}$ Centre for Technology in Water and Wastewater, School of Civil and Environmental Engineering, University of Technology Sydney, Sydney, NWS 2007, Australia

${ }^{b}$ Joint Research Centre for Protective Infrastructure Technology and Environmental Green Bioprocess, School of Civil and Environmental Engineering, University of Technology Sydney, Ultimo, NWS 2007, Australia and Department of Environmental and Municipal Engineering, Tianjin Chengjian University, Tianjin 300384, China

${ }^{c}$ Department of Environmental Energy Engineering, Kyonggi University, 442-760, Republic of Korea

${ }^{d}$ Institution of Research and Development, Duy Tan University, Da Nang, Vietnam

${ }^{e}$ Strategic Water Infrastructure Laboratory, School of Civil Mining and Environmental Engineering, University of Wollongong, Wollongong, NSW 2522, Australia

* Corresponding authors: Huu Hao Ngo, E-mail address: ngohuuhao121@gmail.com 


\section{Abstract}

Due to the impact of methane, carbon dioxide and nitrous oxide on global warming, the quantity of these greenhouse gases (GHG) emissions from municipal wastewater treatment plants (WWTPs) has attracted more and more attention. Consequently, GHG emssions from the two popular treatment technologies: anaerobic/ anoxic/ oxic (AAO) process and sequencing batch reactor (SBR) should be properly identified and discussed toward the current situation in developing countries. Direct and indirect carbon dioxide (with and/or without including in Intergovernmental Panel on Climate Change (IPCC) report) are all discussed in this article. This literature study observed that a quantity of total carbon dioxide emissions from SBR $\left(374 \mathrm{~g} / \mathrm{m}^{3}\right.$ of wastewater) was double that of AAO whilst ten per cent of these was direct carbon dioxide. Methane emitted from an SBR was $0.50 \mathrm{~g} / \mathrm{m}^{3}$ wastewater while $0.18 \mathrm{~g} \mathrm{CH}_{4} / \mathrm{m}^{3}$ wastewater was released from an AAO. The level of nitrous oxide from AAO and SBR accounted for $0.97 \mathrm{~g} / \mathrm{m}^{3}$ wastewater and $4.20 \mathrm{~g} / \mathrm{m}^{3}$ wastewater, respectively. Although these results were collected from different WWTPs and where influent was in various states, GHGs emitted from both biological units and other treatment units in various processes are significant. The results also revealed that aerated zone is the major contributing factor in a wastewater treatment plant to the large amount of GHG emissions.

Keywords: Greenhouse gases (GHG) emissions, wastewater treatment plants, anaerobic/ anoxic/oxic process, sequencing batch reactor. 


\section{Introduction}

Many recent studies have revealed that wastewater sanitation operations are related to global warming and climate change (Koutsou et al., 2018). Greenhouse gases (GHG) emanating from the waste and wastewater sector account for $2.8 \%$ of GHG (IPCC, 2007). While they are an important part of wastewater conservation strategy, wastewater treatment plants (WWTPs) contribute to GHG emissions (Koutsou et al., 2018) and global warming. GHG emissions from WWTPs including methane, carbon dioxide and nitrous oxide are categorized as direct GHG emissions and indirect GHG emissions (Polruang et al., 2018). Direct GHG emissions are emitted from biological treatment processes. Carbon dioxide is major released from microbial respiration activities while nitrous oxide is fluxed from denitrification, nitrification stages, and methane mainly comes from anaerobic digestion (Zhang et al., 2017). Indirect GHG emissions consist of internal and external emissions. The indirect internal gases are related to power consumption (Parravicini et al., 2016), or thermal energy, and the indirect external emissions are from activities outside the WWTPs (Mannina et al., 2016). The most significant GHG emissions are emitted from electricity and biological treatment, while indirect emissions from construction materials, chemicals and transports account for $6 \%, 0.18 \%$ and $0.4 \%$ of the total GHG, respectively (Chai et al., 2015).

The combined effect of different gases in the differing times is estimated by using the global warming potential (GWP) and referenced to carbon dioxide (IPCC, 2014a). Methane is a significant contributor to climate change, equivalent to 28 times of carbon dioxide over a 100-year time horizon based on the Fifth Assessment Report (IPCC, 2014b). More than 70\% of methane emissions originate from human activities (Augenbraun et al., 1997). Methane emissions from wastewater treatment are estimated to increase by 1.3 times between 1970 and 2012 (the equivalent 6.6 to 8.8 billion tons of carbon dioxide), especially in the rapidly developing countries of Africa, the Middle East, Central and South America (Janssens- 
Maenhout et al., 2017b). Janssens-Maenhout et al. (2017a) reported that wastewater treatment contributed 37 million tons of methane, accounting for more than $55 \%$ of global methane emissions from the waste sector in 2012 (Figure 1). Methane gas is generated as a by-product of anaerobic digestion in sewage treatment systems. It can be collected and used as an energy source inside the WWTPs, and indirectly reduces carbon dioxide emissions (Oshita et al., 2014). During the anaerobic digestion stage of the treatment process, methane gas is emitted, which amounts to $97.6 \%$ of the total methane from the WWTP (Préndez et al., 2008).

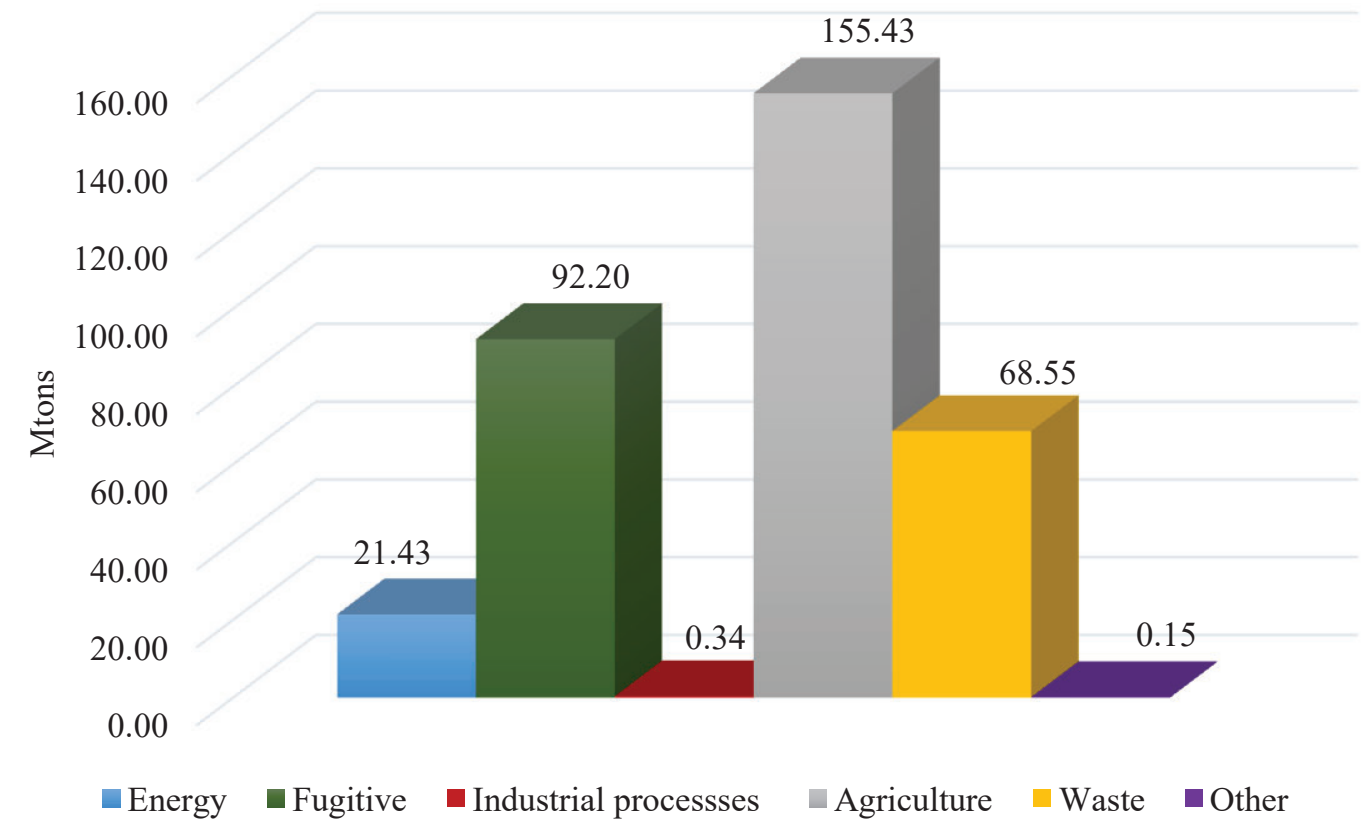

Fig 1. Global Methane Emission by sectors in 2012, source (Janssens-Maenhout et al., 2017a)

Nitrous oxide is an important GHG, which has a GWP of 265 carbon dioxide equivalents and contributes significantly to the GHG footprint of WWTPs (IPCC, 2014b). In some cases, the quantity of nitrous oxide emissions accounts for over $88 \%$ of the total greenhouse gases released from the WWTPs (Daelman et al., 2013). The nitrous oxide emissions from wastewater management accounts for about $26 \%$ of the total GHG emitted from the water 
sector (Frison et al., 2015). Centralised aerobic WWTPs with nitrification and denitrification processes produce small but distinct amounts of nitrous oxide (IPCC, 2006). Estimates of global nitrous oxide emissions from wastewater are incomplete and are based only on human sewage treatment. However, global nitrous oxide emissions indicate an increase from 153.5 kiloton (kt) of nitrous oxide to $315.7 \mathrm{kt}$ nitrous oxide between 1970 and 2012 as shown in Figures. 2 (Janssens-Maenhout et al., 2017a).

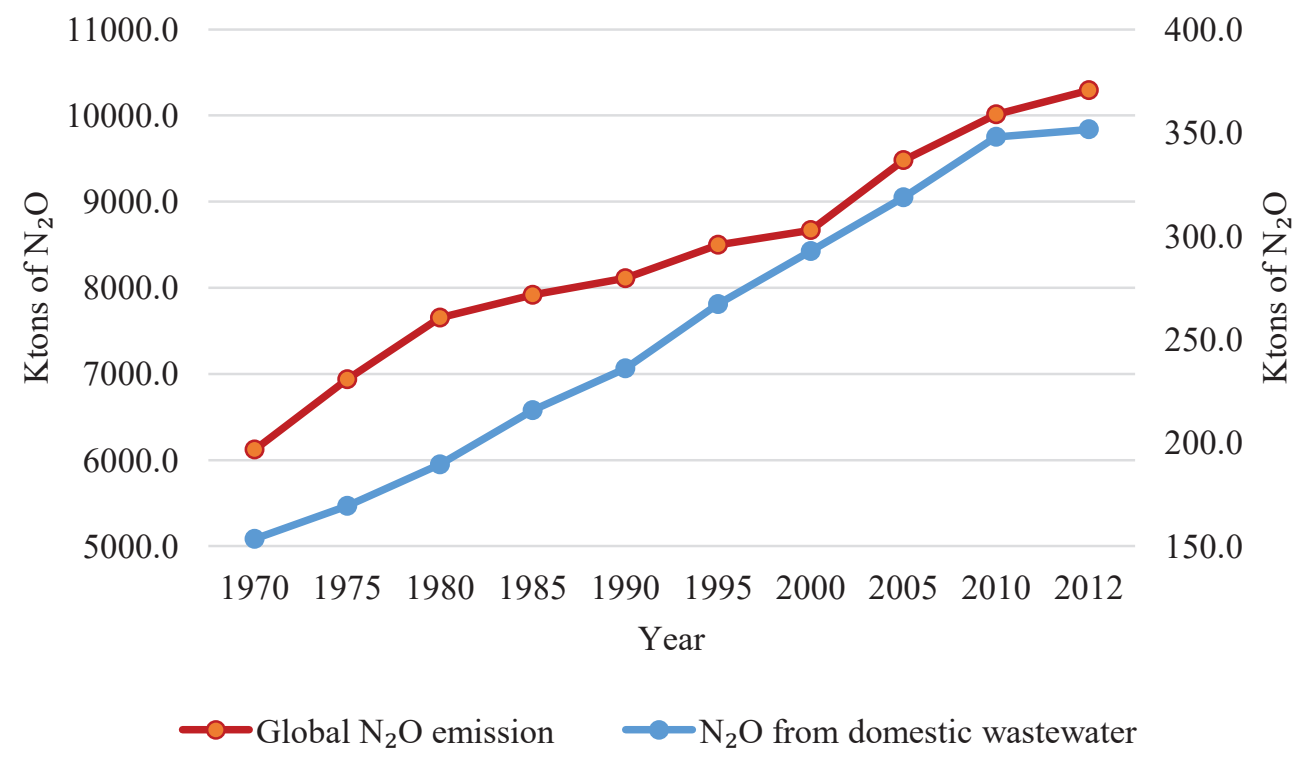

Fig 2. Total global $\mathrm{N}_{2} \mathrm{O}$ emission and $\mathrm{N}_{2} \mathrm{O}$ emission from domestic wastewater, source (Janssens-Maenhout et al., 2017b)

Carbon dioxide emissions from WWTPs relate to energy consumption, chemical usage and microbial activities (Bao et al., 2015). Direct carbon dioxide emissions from biological wastewater treatment processes are a short-lived biogenic carbon type and do not contribute significantly to total GHG emissions (IPCC, 2014b). However, the results show that current GHG accounting guidelines, which assume that all carbon dioxide emissions from WWTPs are biogenic, may lead to underestimation of total GHG emissions (Law et al., 2013). Indirect carbon dioxide is generated from energy and chemical consumption. Therefore, carbon dioxide emissions are assessed based on the energy demand of the WWTPs. Some studies on 
carbon dioxide emissions from WWTPs focus on both direct and indirect carbon dioxide emissions (Campos et al., 2016). Some studies ignore the notion that carbon dioxide emissions from wastewater are of biogenic origin and assert that both non-biogenic and biogenic sources are significant in mitigating emissions (Kosse et al., 2018b). The studies showed that $25 \%$ of the dissolved organic carbon in wastewater is fossil carbon (Chai et al., 2015) and more than $10 \%$ of the carbon dioxide emissions from WWTP are derived from fossil sources which contributed short-term organic carbon dioxide, and to the unaccounted for GHG (Schneider et al., 2015). The fossil carbon component are emitted via effluent discharge, along cwith biosolids and aerobic biodegradation (Law et al., 2013). All sources of carbon dioxide should be taken into account when estimating the quantity of GHG emissions from WWTPs (Garrido-Baserba et al., 2015). There is a global trend of increasing carbon dioxide emissions from wastewater treatment, as in Figure 3.

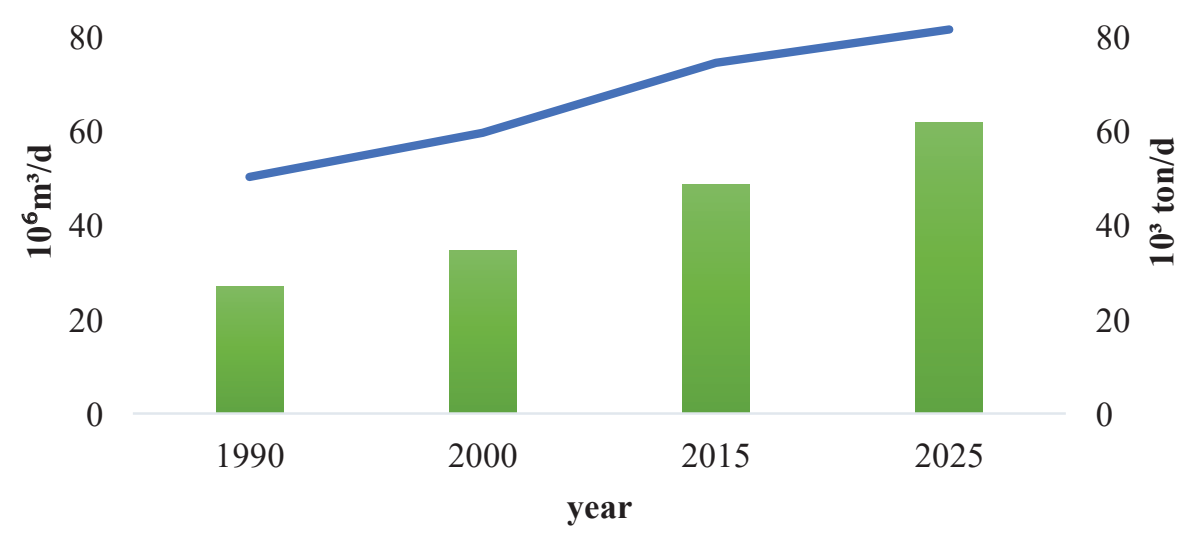

Global Urban Wastewater Sewage production
Global Carbon dioxide Produced From Sewage

Figure 3. Global sewage $\mathrm{CO}_{2}$ production (Rosso et al., 2008)

In recent years, biological wastewater treatment is favoured over chemical treatment (Mulkerrins et al., 2000). Biological sewage treatment is an effective process to remove organic matter and nutrients to discharge and reuse, however, contributes significant sources 
of GHG emissions (Spinelli et al., 2018). The performance of biological wastewater treatment process is based on the activity of microbial for nitrogen and phosphorus removal. According to the principles of biological wastewater treatment, the amount of GHG emissions from WWTPs is related to the type of treatment process (Yan et al., 2014). Both anaerobic/ anoxic/ oxic (AAO) and sequencing batch reactor (SBR) are popular biological nutrient removal systems in many developing countries where wastewater plants' odour is a significant problem. This situation not only affects the community's health but also contributes to global warming as the result of the greenhouse effect. The quantity of GHG emissions from WWTPs was calculated based on on-site and off-site gases. The on-site GHG emissions are collected from the biological treatment process, sludge treatment area and biogas combustion activities. The off-site gases emissions from energy consumption; sludge combustion, disposal and reuse and wastewater discharge. The quantity of GHG emissions from biological wastewater treatment processes tends to increase annually and contributes to total GHG emissions.

Only a few studies on GHG emissions from both AAO and SBR WWTPs measure the volume of GHG emissions calculated or identify the main emissions (Chai et al., 2015; Ren et al., 2015). Certain studies focused solely on specific emissions, such as methane (Liu et al., 2014), nitrous oxide (Massara et al., 2017) or carbon dioxide (Kosse et al., 2018b). Several factors affecting the emissions have been reported and studied. Although various quantification methods were applied, there is a high degree of uncertainty. Due to the variation in the results, it is difficult to determine the relationship between these factors and the quantity of GHG emissions through the existing estimation methods. None of the studies indicated the overall impact of these factors in respect to total GHG emissions from biological treatment processes. The limitations of the existing measurement methods and the 
relationship between these factors makes it difficult to develop effective mitigation strategies for GHG emissions from WWTPs.

This review article critically analyses the occurrence of GHG emissions during the biological treatment process and compares the relative quantities of methane, carbon dioxide and nitrous oxide emissions from both AAO and SBR. The article shows the need for future research on determining the indicators that influence total GHG emissions and the relationship between these indicators.

\section{Methodology}

To analyse the impacts of WWTPs by reviewing the quantity of GHG emissions, the paper is structured as follows: the next section (Section 3) presents the overview of GHG emissions from two typical wastewater treatment processes namely the Anaerobic - Anoxic - Oxic (AAO) and the Sequencing Batch Reactor (SBR). Section 4 includes the evaluation of estimation methods in the reviewed papers and challenges in investigating the impact factors that influence the volume of GHGs emitted. The future research gives some directions to build up the strategies for mitigating GHG emissions from WWTPs. The last section (Section 5) is dedicated to the conclusion.

\section{GHG emissions from two common wastewater treatment processes}

There are numbers of studies evaluated GHG emissions from WWTP. The papers, which indicated the volume of GHG emissions from AAO and/or SBR processes, were selected to reviewed in this study, as can be seen in Table 1.

Table 1. Articles include in the review and main parameters

\begin{tabular}{ccccc}
\hline References & Type of & WWTP capacity & GHG & Collecting/ \\
& treatment & / Influent & & Quantifying \\
& & & \\
\hline
\end{tabular}




\begin{tabular}{|c|c|c|c|c|}
\hline & & characteristic & & method \\
\hline (Kampschreur & SBR & Laboratory & $\mathrm{N}_{2} \mathrm{O}$ & Micro-sensor/ \\
\hline et al., 2008) & & scale & & Formulation \\
\hline (Foley et al., & SBR & $137\left(\mathrm{ML} \mathrm{d}^{-1}\right)$ & $\mathrm{N}_{2} \mathrm{O}$ & Gas hood/ Gas \\
\hline 2010) & AAO & $25\left(\mathrm{ML} \mathrm{d}^{-1}\right)$ & & chromatograph \\
\hline (Law et al., & SBR & Laboratory & $\mathrm{N}_{2} \mathrm{O}$ & Micro-sensor/ \\
\hline 2011) & & scale & & Formulation \\
\hline (Wang et al., & AAO & $3 \times 10^{5} \mathrm{~m}^{3}$ day $^{-1}$ & $\mathrm{I}_{4}$ & Gas hood/ Gas \\
\hline 2011) & & & & chromatograph \\
\hline (Ren et al., & Reverse AAO & $5 \times 10^{4}$ & $\mathrm{~N}_{2} \mathrm{O}, \mathrm{CH}_{4}$ & Gas hood/ Gas \\
\hline 2013) & & & & chromatograph \\
\hline (Rodriguez- & SBR & Laboratory & $\mathrm{N}_{2} \mathrm{O}$ & Micro-sensor/ \\
\hline Caballero et al., & & scale & & Gas analyser \\
\hline 2013) & & & & \\
\hline (Sun et al., & SBR & $10^{4} \mathrm{~m}^{3}$ day $^{-1}$ & $\mathrm{~N}_{2} \mathrm{O}$ & Gas hood/ Gas \\
\hline 2013a) & & $5 \times 10^{5} \mathrm{~m}^{3}$ day $^{-1}$ & & chromatograph \\
\hline (Sun et al., & & $8 \times 10^{4} \mathrm{~m}^{3}$ day $^{-1}$ & $\mathrm{~N}_{2} \mathrm{O}$ & Gas hood/ Gas \\
\hline 2013b) & & & & chromatograph \\
\hline (Liu & SBR & $8 \times 10^{4} \mathrm{~m}^{3}$ day $^{-1}$ & $\mathrm{CH}_{4}$ & Gas hood/ Gas \\
\hline 2014) & AAO & $5 \times 10^{5} \mathrm{~m}^{3}$ day $^{-1}$ & & chromatograph \\
\hline (Sun et al., & SBR & $8 \times 10^{4} \mathrm{~m}^{3}$ day $^{-1}$ & $\mathrm{~N}_{2} \mathrm{O}$ & Gas hood/ Gas \\
\hline 2014) & & & & chromatograph \\
\hline (Yan et al., & $\mathrm{AAO}$ & $23 \times 10^{4} \mathrm{~m}^{3}$ day $^{-1}$ & $\mathrm{~N}_{2} \mathrm{O}, \mathrm{CH}_{4}, \mathrm{CO}_{2}$ & Gas hood/ Gas \\
\hline 2014) & & & & chromatograph \\
\hline (Bao et al., & SBR & $\mathrm{COD} 414 \mathrm{mg} / \mathrm{L}$ & $\mathrm{CO}_{2}$ & Gas hood/ Gas \\
\hline
\end{tabular}


chromatograph

(Frison et al.,

SBR

$70000 \mathrm{PE}$

$\mathrm{N}_{2} \mathrm{O}, \mathrm{CH}_{4}, \mathrm{CO}_{2}$ Gas hood/ Gas

2015)

chromatograph

(Ren et al.,

AAO

$3 \times 10^{5} \mathrm{~m}^{3}$ day $^{-1}$

$\mathrm{N}_{2} \mathrm{O}, \mathrm{CH}_{4}, \mathrm{CO}_{2}$

Gas hood/ Gas

2015)

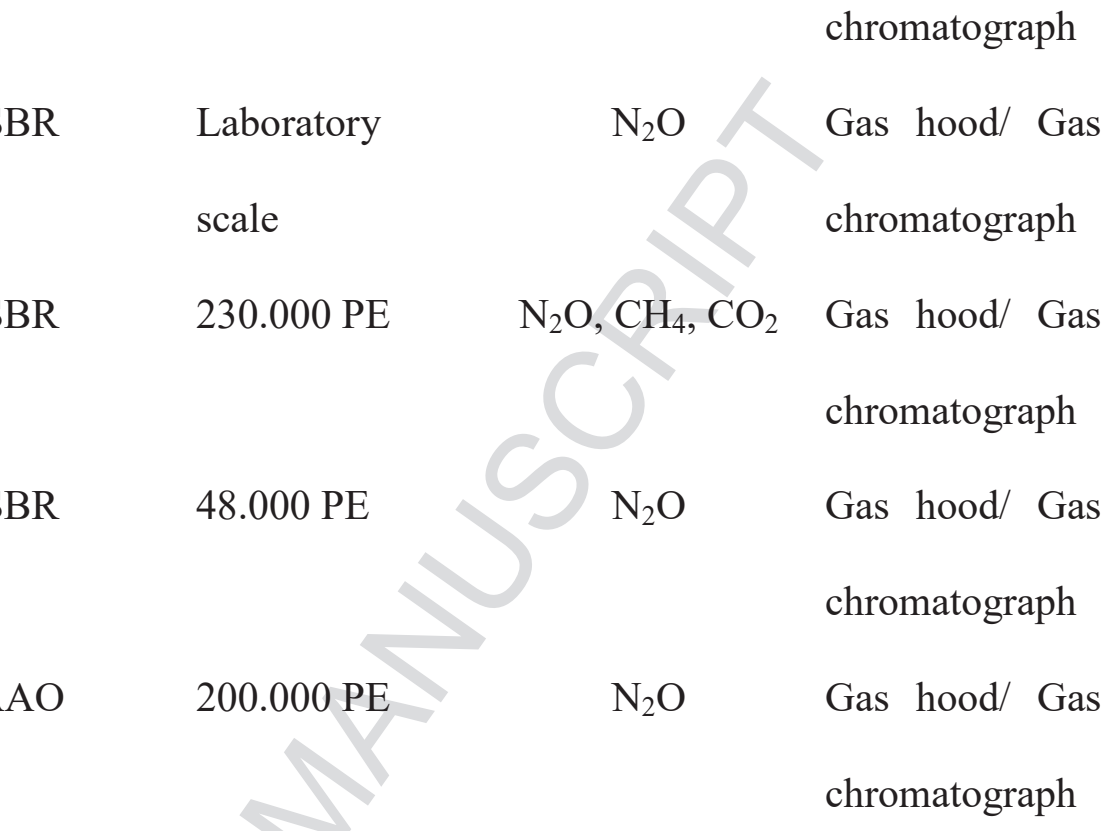

(Toor et al.,

2015)

(Bao et al.,

2016)

(Marques et al.,

2016)

(Wang et al.,

AAO

2016)

chromatograph

\subsection{AAO process}

The AAO process is one of the most popular biological nutrient removal techniques, and consists of an anaerobic stage followed by an anoxic and oxic stage, where large amounts of GHG are emitted under various conditions. The AAO process requires a combination of anaerobic tanks, anoxic tanks and oxic tanks, with recirculation from the oxic tank to the anoxic tank for nitrogen and phosphorus removal. The treatment process consists of three steps. Firstly, the influent return activated sludge flows into the anaerobic tanks. Secondly, the wastewater flows into anoxic tanks with propellers to control water flow, where denitrification and nitrogen removal occur. Thirdly and finally, wastewater enters the oxic tanks via aeration equipment. In the initial anaerobic tanks, the organic substrate is sequestered by phosphorus accumulating bacteria under anaerobic condition. This results in 
low or no organic substrate available for denitrifiers in anoxic tank, and the denitrification performance of the AAO process is poor (Fang et al., 2016). A study conducted over 153 WWTPs involving eight technologies, that is conventional activated sludge, anoxic-oxic, anaerobic-anoxic-oxic, oxidation ditch, sequencing batch reactor, biological filter, biological contact oxidation, and membrane bioreactor. AAO emerged as having the second best efficiency in term of technologies investment, energy consumption, pollutant removal and GHG emissions (Zeng et al., 2017). When comparing conventional activated sludge plants of the same size, with the same volume of treated wastewater per day, the AAO plants have a similar level of investment, but less electricity input. Furthermore, the AAO plants could also achieve the greater removal of pollutants, with lower chemical oxygen demand (COD) and total phosphorus (TP) and with less methane and nitrous oxide generated.

\section{a. Methane emissions}

One of the first studies that measured the quantity of direct methane gas emissions emitted from the treatment process was undertaken in 1993 (Czepiel et al., 1993). The main source of methane emissions is the sludge line units, which contribute $72 \%$ of total methane released from a WWTP. The remaining emissions are from the biological reactors (Campos et al., 2016). Previous experiments showed that methane emissions occur in all processing units (Liu et al., 2014). Wang et al. (2011) measured methane from each processing unit of Jinan WWTP in China, which adopts AAO process treatment. The capacity of Jinan WWTP is $3 \times 10^{5} \mathrm{~m}^{3}$ day ${ }^{-1}$ with serving size population of about $1,500,000$. The number of sampling points was determined due to the dissolved oxygen (DO) change and the water surface area. In the aerated area, which includes aerated grit chambers and oxic tanks, a $40 \mathrm{~L}$ polyethene bag was used to measure methane emission. Methane emitted from remaining treatment units in non-aerated places was collected by flux hood technique. The total result of annual 
methane of each unit showed that most of the methane was emitted from the anaerobic tanks and oxic tanks (Wang et al., 2011) and presented in Table 2.

Another full-scale research showed the same trend of methane emission from each treatment units under different conditions (Liu et al., 2014). In that study, methane was quantified with a similar technique from the AAO process in a municipal WWTP in China. This WWTP serves a population of $1,200,000$ with a capacity of $5 \times 10^{5} \mathrm{~m}^{3} /$ day. Liu et al. (2014), in their experiment, discovered that most methane was emitted from the oxic tanks. The anaerobic tanks produced the second highest amount of methane as summarised in Table 2 (Liu et al., 2014).

Table 2. Methane emitted from each zone. Source (Liu et al., 2014; Wang et al., 2011)

\begin{tabular}{ccccccc}
\hline $\begin{array}{c}\text { Process } \\
\text { unit }\end{array}$ & $\begin{array}{c}\text { Surface } \\
\text { area }\left(\mathrm{m}^{2}\right)\end{array}$ & $\begin{array}{c}\text { (Liu et al., 2014) } \\
\text { Dissolved } \mathrm{CH}_{4} \\
(\mathrm{mg} / \mathrm{L})\end{array}$ & $\begin{array}{c}\text { Emission } \\
\left(\mathrm{g} \mathrm{CH}_{4} / \mathrm{m}^{3}\right)\end{array}$ & $\begin{array}{c}\text { Surface } \\
\text { area }\left(\mathrm{m}^{2}\right)\end{array}$ & $\begin{array}{c}\text { (Wang et al., 2011) } \\
\mathrm{CH}_{4}(\mathrm{mg} / \mathrm{L})\end{array}$ & $\begin{array}{c}\text { Emission } \\
\left(\mathrm{g} \mathrm{CH}_{4} / \mathrm{m}^{3}\right)\end{array}$ \\
\hline $\begin{array}{c}\text { Aerated grit } \\
\text { tank }\end{array}$ & 504 & 0.6 & 0.026 & 350 & 0.015 & 0.022 \\
$\begin{array}{c}\text { Anoxic } \\
\text { tank }\end{array}$ & 3,564 & 0.13 & 0.007 & 6,300 & 0.001 & 0.004 \\
$\begin{array}{c}\text { Anaerobic } \\
\text { tank }\end{array}$ & 3,564 & 0.15 & 0.019 & 6,400 & 0.006 & 0.073 \\
Oxic tank & 24,945 & $0.0005-0.02$ & $\mathbf{0 . 3 7 1}$ & 9,400 & 0.0002 & $\mathbf{0 . 0 8 6}$ \\
\hline
\end{tabular}

One more full-scale research investigated the quantity of GHG emissions from AAO treatment process in a WWTP in China over a nine-month period. The plant's capacity was $23 \times 10^{4} \mathrm{~m}^{3}$ per day with wastewater source from domestic. The results indicated that the highest methane emissions were emitted from the grit tank at a rate of $2.2 \mathrm{~g} /\left(\mathrm{m}^{2} . \mathrm{hr}\right)$. The aerobic area released nearly three times the volume of methane than the grit tank, which amounted to $57.4 \mathrm{~kg} /$ day and $18.3 \mathrm{~kg} /$ day, respectively (Yan et al., 2014).

In these experiments, there is no detailed description of the operating conditions of each unit and the varying results may be due to conditions. The major conclusion is that oxic tank, the 
largest of all units, released most of the methane. Referring to the second highest quantity of methane produced in Table 2. This illustrates how the anaerobic tank and the primary settling tank are the main components. The factors that may influence these emissions have been identified. The volume of dissolved methane was measured in these tanks, and the highest concentration of dissolved methane was found in the primary settling tank, followed by the aerated grit tank. Under the mechanical aeration, the DO concentration increased and inhibited methane formation. The dissolved methane released significant amounts of methane emissions and this appears to explain the quantity of GHG emissions from these two tanks. Finally, when analysing GHG emissions using aeration efficiencies, the dissolved methane in the oxic tank unit was lowest; the largest quantity of methane is the result of high aeration stripping under specific conditions. In addition, other indicators explain these results as a factor of the surface area of each tank and the process. For example, the plant described by Liu et al. (2014) had a total capacity of more than 1.5 times than that of the plant described by Wang et al. (2011), and the oxic tank was 2.6 times larger. In the Table 1, the larger oxic tank shows greater emissions compared to the smaller oxic tank. Similar trend could be found in the anaerobic tanks. Moreover, Ren et al. (2015) found that the concentration of organic material in the wastewater is another condition for methane emissions. There is a need for future research on the impact of DO concentration on methane emissions.

\section{b. Carbon dioxide}

Only a few of the studies undertaken on carbon dioxide from WWTPs focused on the direct emissions. Bao et al. (2015) measured the volume of carbon dioxide in each treatment tank in the AAO process, namely the aerated grit tank, primary sediment tank, anoxic tank, anaerobic tank, oxic tank and final clarifier. The aerated grit tank, which has the smallest surface area, produced the largest volume of carbon dioxide emissions over the largest range of dissolved carbon dioxide. This was followed by the carbon dioxide emissions from the oxic tank as a 
result of the respiration and aeration stripping processes. In contrast, the primary sedimentation tank and final clarifier, which had the largest surface areas, emitted the smallest quantity of carbon dioxide due to limited biological activities and little microbial respiration, respectively. A similar trend was found in the research of Kyung et al. (2015).

Table 3 shows that in the AAO process, in the aerated units, direct emissions are $96 \%$ of the total emissions. Although the oxic tank has a large surface area, high emissions of carbon dioxide were found during the early stages of aeration the oxic tank and carbon dioxide decreased dramatically at a later stage.

Results from other studies showed that carbon dioxide emission rate in the oxic tanks was much higher than in the anaerobic and anoxic tank (Ren et al., 2015). The highest rate of emission flux was from the aerobic zone, which amounted to $68.2 \mathrm{~g} /\left(\mathrm{m}^{2} . \mathrm{hr}\right)$, whilst there were negligible emissions of carbon dioxide from the anaerobic tank and anoxic tank (Yan et al., 2014). Level of carbon dioxide emissions from the grit tank and the oxic tank differ between reports and season. However, the aerobic area emitted significant volumes of carbon dioxide.

Table 3. $\mathrm{CO}_{2}$ emissions from each unit in the AAO treatment process, source (Bao et al., 2015; Yan et al., 2014)

\begin{tabular}{ccccc}
\hline TREATMENT UNIT & \multicolumn{2}{c}{$\begin{array}{c}\text { (Bao et al., 2015) } \\
\mathrm{CO}_{2} \text { emission } \\
(\mathrm{kg} / \mathrm{d})\end{array}$} & $\begin{array}{c}\text { Area }\left(\mathrm{m}^{2}\right) \\
\text { Area }\left(\mathrm{m}^{2}\right)\end{array}$ & $\begin{array}{c}2014) \\
\mathrm{CO}_{2} \text { emission } \\
(\mathrm{kg} / \mathrm{d})\end{array}$ \\
\hline Aerated grit tank & 504 & $1,879.13$ & 346 & 78 \\
Anoxic tank & 3,564 & 215.66 & - & 172 \\
Anaerobic tank & 3,564 & 242.00 & - & 70 \\
Oxic tank & 25,011 & $72,651.20$ & 15,051 & 24,637 \\
\hline
\end{tabular}

In the AAO process, the inducements for release of carbon dioxide released are the mechanical aeration and the concentration of dissolved carbon dioxide in the influent. In 
general, carbon dioxide is produced through two processes, namely the degradation of organic pollutants by microbial communities and biomass respiration. The latter produces less carbon dioxide emission when compared with the biological process (Schneider et al., 2015). In the initial stages in the oxic tank, carbon dioxide is generated mainly through the degradation of organic matter through aerobic respiration. During the latter stages of the oxic tank, there is a reduction of carbon dioxide flux during the endogenous respiration period (Bao et al., 2015).

\section{c. Nitrous oxide}

In the WWTP, most nitrous oxide is emitted in the biological nitrogen removal process, which consists of nitrification and denitrification. Denitrification involves the anoxic reduction of nitrates which is converted into dinitrogen gas by the microorganism. Nitrification includes two steps: ammonia is oxidised to nitrite and nitrite is transferred to nitrate by nitrite-oxidising bacteria (Aboobakar et al., 2013). In the WWTPs, the production of nitrous oxide mainly occurs in the activated sludge units (Yang et al., 2009). In the biological treatment process, zones that have intermittent aeration have higher nitrous emissions than other zones (Kosonen et al., 2016).

The largest amount of nitrous oxide was emitted in the oxic zone due to nitrifying activities of the ammonia-oxidising bacteria (AOB) (Massara et al., 2017), followed by anaerobic zone and then the aerated grit tank, as indicated in Table 4. Foley et al. (2010) collected results from seven WWTPs and found that the amount of emissions from the anoxic surface area and the anaerobic surface area is much smaller than emissions from aerated zones. Ren et al. (2015) measured nitrous oxide emissions under different influent carbon: nitrogen $(\mathrm{C} / \mathrm{N})$ ratio. Using six case studies, it was found that the oxic tank contributed the most nitrous 
oxide emissions while emissions from the anoxic tank and anaerobic tank were insignificant (Ren et al., 2015).

Table 4. $\mathrm{N}_{2} \mathrm{O}$ emission in AAO process, source (Ren et al., 2013; Sun et al., 2013a; Yan et al., 2014)

\begin{tabular}{cccc}
\hline TREATING UNIT & \multicolumn{3}{c}{$\mathrm{N}_{2} \mathrm{O}$ EMISSION $\left(\mathrm{kg} \mathrm{d}^{-1}\right)$} \\
\hline Aerated grit tank & 5.51 & 24.60 & 6.00 \\
AAO anoxic zone & 1.32 & 22.10 & 14.05 \\
AAO anaerobic zone & 7.59 & 10.80 & 7.66 \\
AAO oxic zone & $\mathbf{4 7 1 . 7 0}$ & $\mathbf{9 7 4 5 . 9 0}$ & $\mathbf{6 0 3 0 . 0 0}$ \\
Reference & Sun et al. (2013) & Yan et al. (2014) & Ren et al. (2013) \\
\hline
\end{tabular}

The results show that nitrous oxide is mainly produced in the oxic zone (Kosonen et al., 2016) instead of transported from previous non-aeration zones (Wang et al., 2016). Kampschreur et al. (2009) showed that nitrous oxide was produced in the anoxic stage and stripped to the gas phase in the aerated zone. Only a small amount of nitrous oxide was found in the anoxic zone because the recycling between aerobic and anoxic tank resulted in the nitrate being mixed with the wastewater in the anoxic zone. The nitrate was reduced by denitrifying bacterial in the anoxic tank (Soda et al., 2013). Emission fluxes from the anaerobic and anoxic zone contributed little to the total emissions (Wang et al., 2016).

Factors related to the quantity of nitrous oxide include DO, dissolved nitrous oxide and the aeration rate. While some scientists agree that the concentration of dissolved nitrous oxide in the wastewater is one of the main factors (Wang et al., 2016), Masuda et al. (2018) found that there was a very difference across studies on the influence of dissolved nitrous oxide to nitrous oxide emissions. Thus, more research on the relationship between dissolved nitrous oxide and nitrous oxide emission is required. An intermittent aeration process makes it 
possible for biological removal of nitrogen to occur, which controls nitrous oxide emissions. Therefore, low DO concentrations and efficient aeration influence the quantity of nitrous oxide emissions.

\subsection{SBR process}

The SBR is an alternative to conventional processes for removing nutrient from wastewater. The SBR is a fill-and-draw activated sludge system for domestic and industrial wastewater treatment. In SBR, all processes are conducted in a single reactor following a sequence of fill, reaction, settling and decanting phase (Puig, 2008). The influent flows into the swirl grit tank to remove solids, then passes through the sewage distribution tank and finally is treated in the SBR tank. The biological nutrient removal process alternates between anoxic and aerobic periods within the treatment cycle.

The SBR has been widely applied in wastewater treatment because it has greater flexibility, control and requires a low-cost investment (Real et al., 2017). The SBR processes are believed to achieve high effluent quality in a very short aeration time as well as to save more than $60 \%$ of the operating cost when compared with the conventional activated sludge process (Singh et al., 2011).

\section{a. Methane emission}

Prior studies have determined the level of methane emissions in each unit and in each phase of the SBR process (Liu et al., 2014). An experiment was conducted in a WWTP, Beijing, China, which has a capacity of $8 \times 10^{4} \mathrm{~m}^{3} /$ day and serves a population of 231,000 . The biological treatment process included six cycles, which were divided into three phases as follows: feeding and aeration phase, settling phase and decanting phase. In the primary treatment units, the swirl grit tank and the sewage distribution tank, the dissolved methane concentrations were higher than in the SBR tanks. There were large amounts of methane 
emissions originating from the swirl grit tank and the first phase of the SBR process. The wastewater that was stirred intensively in the swirl grit tank led to the dissolved methane was fluxed, subsequently causing a large amount of methane to be emitted. The gas flux from the feeding and aeration phase was the highest for the whole SBR process due to strong mechanical aeration (Figure 4).

Another study was conducted by Bao et al. (2016) in which the SBR process was divided into 4 phases that in total lasted 4 hours: 1 hour for aeration feeding, 1 hour for aeration-nonfeeding, 1 hour for settling and remaining 1 hour for decanting phase. The study indicated that the first two phases of biological treatment produced the most methane during the SBR process, ranging from 2.5 to $73.3 \mathrm{~g} \mathrm{CO}_{2}$ equivalent $\left(\mathrm{gCO}_{2}\right.$-eq) $\mathrm{m}^{-3}$ wastewater with an average of $4.5 \mathrm{gCO}_{2}$-eq m${ }^{-3}$ wastewater or $0.16 \mathrm{gCH}_{4} \mathrm{~m}^{-3}$ wastewater (Bao et al., 2016). In the feeding and aeration phases, methane oxidation occurred, and a great deal of methane was stripped. However, the quantity of methane produced in aeration during the feeding stage was even higher than that of the aeration in the non-feeding stage. The settling and decanting phases did not contribute to methane emissions.

The results are varied, but the same trend is found in these papers and is shown in Table 5.

Table 5. Methane emitted from different units in the SRB process, source (Bao et al., 2016; Liu et al., 2014)

\begin{tabular}{cccccc}
\hline Process unit & $\begin{array}{c}\text { Swirl } \\
\text { tank }\end{array}$ & $\begin{array}{c}\text { Sewage distribution } \\
\text { tank }\end{array}$ & $\begin{array}{c}\text { Feeding and aeration } \\
\text { phase }\end{array}$ & $\begin{array}{c}\text { Settling } \\
\text { phase }\end{array}$ & $\begin{array}{c}\text { Decanting } \\
\text { phase }\end{array}$ \\
\hline $\begin{array}{c}\text { (Bao et al., } \\
\text { 2016) }\end{array}$ & 0.000 & 0.000 & 2.610 & 0.000 & 0.050 \\
$\begin{array}{c}\text { (Liu et al., } \\
\text { 2014) }\end{array}$ & 0.001 & 0.001 & 1.590 & 0.001 & 0.001 \\
\hline
\end{tabular}

\section{b. Carbon dioxide}


In the SBR tank, the organic matters present in the influent was degraded biologically and produced a large amount of carbon dioxide. A full-scale study about carbon dioxide in SBR WWTP found that the swirl grit tank produced a small amount of carbon dioxide $(0.045$ $\mathrm{gCO}_{2}$-eq $\mathrm{m}^{-3}$ wastewater) as a result of using a swirl mixer instead of aeration equipment (Bao et al., 2016). The volume of emissions from the sewage distribution tank was small because of the low levels of nitrification and denitrification with shorter hydraulic retention time. However, previous research has confirm that the largest amount of carbon dioxide was detected in the feeding and aeration phases due to the aeration respiration and aeration stripping processes (Bao et al., 2015). The amount of carbon dioxide released from feeding and aeration period was an average of $334.6 \mathrm{gCO}_{2}-\mathrm{eq} \mathrm{m}^{-3}$ wastewater (Bao et al., 2015) and $343.86 \mathrm{gCO}_{2}$-eq $\mathrm{m}^{-3}$ wastewater (Bao et al., 2016), which amounted to $99 \%$ of the total emission. Most of the carbon dioxide was emitted at the initiation of the feeding and aeration phases.

Aeration during the feeding and aeration periods make it possible for nitrification and denitrification to occur during the treatment process. The experiment showed that the concentration of dissolved carbon dioxide in the swirl grit tank was much higher than in the aerated tank. In the settling phase and decanting phase, only a small amount of carbon dioxide was generated in the absence of aeration due to anaerobic respiration. Only 1.06 and $0.84 \mathrm{gCO}_{2}$-eq $\mathrm{m}^{-3}$ wastewater was fluxed during the settling and decanting phase (Bao et al., 2015).

\section{c. Nitrous oxide}

Nitrous oxide has a large impact on the overall carbon footprint of the WWTP using SBR for the biological wastewater treatment. Many different quantification techniques are applied to measure nitrous oxide emission from WWTPs. Research at full-scale WWTPs, using both gas 
sensor and online gas analyser methods, indicated that nitrous oxide could be emitted during nitrogen removal; however, a large variation in reported emission values is evident (Foley et al., 2010). Marques et al. (2016) conducted a nitrous oxide measurement in a full-scale SBR plant by using a conventional online gas analyser. According to this research, liquid-phase nitrous oxide measurements coupled with liquid-gas mass transfer estimations constituted an alternative methodology for assessing emission factors. Nitrous oxide produced in liquidphase can transfer to the gas-phase when nitrous oxide is over-saturated, or stripped by aeration, which facilitates the transfer of dissolved nitrous oxide (Law et al., 2011). Marques et al. (2016) discovered differences in the results of these two methods, and the anoxic emissions were relatively low. More than $90 \%$ of nitrous oxide emissions occurred during the aeration phase due to air-stripping of dissolved nitrous oxide (Kampschreur et al., 2009). Some differences observed between nitrous oxide flux in the feeding phase and aeration period as shown in Table 6. However, these phases produce much higher nitrous oxide emissions than others phases (Sun et al., 2014). Nitrous oxide emissions during the aeration feeding period were $100 \mathrm{~g} \mathrm{CO}_{2}$-eq $\mathrm{m}^{-3}$, which was higher than the aeration non-feeding period (Bao et al., 2016). Organic matter influences the nitrification efficiency and nitrous oxide production because firstly, organic matter promotes the growth of heterotrophic microorganisms; and secondly, consumes DO (Toor et al., 2015). During the first 30 minutes of the feeding phase, less oxygen was consumed because organic matters existed in small concentrations in wastewater, which led to the value of DO increasing. At that time, nitrous oxide emissions mainly came from the dissolved nitrous oxide in the influent. Following the feeding period, organic matter gradually accumulated, and more oxygen was consumed, which resulted in DO value declining. Poorly DO led to a large quantity of nitrous oxide, indicating the occurrence of incomplete nitrification (Frison et al., 2015). The total amount of 
nitrous oxide emitted from the aeration phase ranged from 394.2 to $1782.4 \mathrm{~g} \mathrm{CO}_{2}$-eq m${ }^{-3}$, with an average of $480.2 \mathrm{~g} \mathrm{CO}_{2}$-eq $\mathrm{m}^{-3}$ (Bao et al., 2016).

Nitrous oxide was emitted during the aeration stage, which included dissolved nitrous oxide produced through incomplete denitrification in the anoxic period and nitrous oxide through incomplete nitrification during the low DO aeration period. Denitrification and nitrification took place during the aeration period, in which most of the emissions occurred, in the feeding and non-feeding period (Sun et al., 2013a). Another reason for the large quantity of nitrous oxide was the high concentration of dissolved nitrous oxide during the feeding and aeration phases and the strong aerobic stirring. The nitrous oxide flux during the settling and decanting phases was nearly undetectable, although a certain amount of nitrous oxide was dissolved in these periods (Sun et al., 2013b).

Table 6. $\mathrm{N}_{2} \mathrm{O}$ emitted from each zone in SBR process, source (Bao et al., 2016; Sun et al., 2014; Sun et al., 2013a)

TREATING UNIT

\begin{tabular}{cccc} 
& Sun et al. (2014) & Sun et al. (2013) & Bao et al.(2016) \\
\hline Swirl grit tank & 0.000032 & 0.00001 & 0.00 \\
Sewage distribution tank & 0.000016 & 0.000003 & 0.00 \\
Feeding period & $\mathbf{1 . 7 8}$ & $\mathbf{2 . 2 3 5 6}$ & $\mathbf{1 . 1 3}$ \\
Aeration period & & $\mathbf{2 . 0 0 1 8 7}$ & $\mathbf{0 . 7 5}$ \\
Settling period & 0.00174 & 0.00187 & 0.0018 \\
Decanting period & 0.0013 & 0.0011 & 0.0015 \\
\hline
\end{tabular}

Law et al. (2011) indicated that the dissolved nitrous oxide was stripped during the aeration phase and nitrous oxide in the non-aerated zone contributed $94 \pm 4 \%$ to the total nitrous oxide emission in the first 15 minutes of the aeration phases. The reason is that the aerobic stage 
takes place after the anoxic stage. The nitrous oxide air bubbles are formed during the anoxic are and are stripped off in the aerobic stage (Frison et al., 2015). During the aeration phase, nitrous oxide continuously flux and the most transfer occurred, resulting in the high volume of emission (Law et al., 2011). Moreover, nitrous oxide flux from the aeration stage decreased when the aeration rate increased (Law et al., 2012). The provision of sufficient aeration time to achieve full ammonia oxidation could mitigate the overall nitrous oxide emissions (Rodriguez-Caballero et al., 2013). The effect of oxygen limitation on nitrous oxide emissions was tested by Kampschreur et al. (2008). The results showed that level of $\mathrm{N}_{2} \mathrm{O}$ increased immediately and reached 5 times upon oxygen depletion.

\section{Critical analysis of the review studies}

\subsection{Evaluation of measuring methods}

\section{a. IPCC guidelines}

One of the most popular methods used to estimate GHG emissions is the IPCC Guidelines for National GHG Inventory (IPCC, 2006). Emissions of methane and nitrous oxide from wastewater treatment are reported under the Waste sector. The quantity of gas was estimated through the application of models or equations.

\section{Calculation of methane emission}

The formulation used to calculate total $\mathrm{CH}_{4}$ emitted from domestic wastewater is described in IPCC guidelines (IPCC, 2006). Using IPCC guidelines is a simple and straightforward method for methane estimating. The formulation based on the annual organic matter in the wastewater, the fraction of wastewater treated anaerobically, the emission factor and the amount of methane recovered from wastewater treatment. Biological oxygen demand (BOD) is one of the principal factors that determine the generation of methane from wastewater. The emission factor is the key to the emission inventory and represents the value of methane 
released to the atmosphere with activities associated with the pollutant (US.EPA, 2016). Default emission factor for methane is recommended when available data is limited.

- Total $\mathrm{CH}_{4}$ emissions from domestic wastewater

$$
\mathrm{CH}_{4} \text { Emissions }=\left[\sum_{i, j}\left(U_{I} \cdot T_{i . j} . E F_{j}\right)\right](T O W-S)-R
$$

where,

$\mathrm{CH}_{4}$ Emissions $=\mathrm{CH}_{4}$ emissions in inventory year, $\mathrm{kg} \mathrm{CH} / \mathrm{yr}$

TOW = total organics in wastewater in inventory year, $\mathrm{kg} \mathrm{BOD} / \mathrm{yr}$

$\mathrm{S} \quad=$ organic component removed as sludge in inventory year, $\mathrm{kg} \mathrm{BOD} / \mathrm{yr}$

$\mathrm{U}_{\mathrm{i}} \quad=$ fraction of population in income group $i$ in inventory year

$\mathrm{T}_{\mathrm{i}, \mathrm{j}} \quad=$ degree of utilisation of treatment/ discharge pathway of system, $j$, for each income group fraction $i$ in inventory year

$\mathrm{i}=$ income group: rural, urban high income and urban low income

$\mathrm{j}=$ each treatment/ discharge pathway or system

$\mathrm{EF}_{\mathrm{j}} \quad=$ emission factor, $\mathrm{kg} \mathrm{CH}_{4} / \mathrm{kg} \mathrm{BOD}$

$\mathrm{R}=$ amount of $\mathrm{CH}_{4}$ recovered in the inventory year, $\mathrm{kg} \mathrm{CH} 4 / \mathrm{yr}$

- $\mathrm{CH}_{4}$ emissions factor for each domestic wastewater treatment/discharge pathway or system.

$$
E F_{j}=B_{o} \cdot M C F_{j}
$$

where,

$\mathrm{EF}_{\mathrm{j}} \quad=$ emission factor, $\mathrm{kg} \mathrm{CH}_{4} / \mathrm{kg} \mathrm{BOD}$ 
$\mathrm{j}=$ each treatment/ discharge pathway or system

Bo $\quad=$ maximum $\mathrm{CH} 4$ producing capacity, $\mathrm{kg} \mathrm{CH} 4 / \mathrm{kg} \mathrm{BOD}$

$\mathrm{MCFj}=$ methane correction factor

- Total organically degradable material in domestic wastewater

TOW $=$ P.BOD . 0.001.I. 365

where,

TOW = total organics in wastewater in inventory year, $\mathrm{kg} \mathrm{BOD} / \mathrm{yr}$

$\mathrm{P} \quad=$ country population in inventory year, (person)

BOD = country-specific per capita BOD in inventory year, $\mathrm{g} / \mathrm{person} / \mathrm{day}$

$0.001=$ conversion from grams BOD to $\mathrm{kg} \mathrm{BOD}$

I $\quad=$ correction factor for additional industrial BOD discharged into sewers

Determining the methane correction factor $(\mathrm{MCF})$ is one of the most difficult part as it based on the fraction of wastewater treated anaerobically. The guidelines suggest a large range of this fraction with the limited condition to apply.

\section{Calculation of nitrous oxide emission}

The equation to calculate total $\mathrm{N}_{2} \mathrm{O}$ emitted from domestic wastewater is described in IPCC guidelines (IPCC, 2006). These formulations could be applied for collected and uncollected wastewater as they are based on nitrogen component in the wastewater.

- $\mathrm{N}_{2} \mathrm{O}$ emissions from wastewater effluent

$$
\mathrm{N}_{2} \mathrm{O} \text { Emission }=N_{\text {EFFLUENT }} \cdot \text { EF EFFLUENT } \cdot 44 / 28
$$

where, 
$\mathrm{N}_{2} \mathrm{O}$ Emission $=\mathrm{N}_{2} \mathrm{O}$ emissions in inventory year, $\mathrm{kg} \mathrm{N} \mathrm{N}_{2} \mathrm{O} / \mathrm{yr}$

$\mathrm{N}_{\text {EFFLUENT }}=$ nitrogen in the effluent discharge to aquatic environments, $\mathrm{kg} \mathrm{N} / \mathrm{yr}$

$\mathrm{EF}_{\text {EFFLUENT }}=$ emission factor for $\mathrm{N}_{2} \mathrm{O}$ emissions from discharged to wastewater, $\mathrm{kg} \mathrm{N} \mathrm{N}_{2} \mathrm{O}-\mathrm{N} / \mathrm{kg} \mathrm{N}$

$44 / 28$ = conversion of $\mathrm{kg} \mathrm{N}_{2} \mathrm{O}-\mathrm{N}$ into $\mathrm{kg} \mathrm{N}_{2} \mathrm{O}$

- Total nitrogen in the effluent

$N_{\text {EFFLUENT }}=\left(P \cdot\right.$ Protein.$\left.F_{N P R} \cdot F_{N O N-C O N} \cdot F_{I N D-C O M}\right)-N_{\text {SLUDGE }}$

where,

$\mathrm{N}_{\text {EFFLUENT }}=$ total annual amount of nitrogen in the wastewater effluent, $\mathrm{kg} \mathrm{N} / \mathrm{yr}$

$\mathrm{P} \quad=$ human population

Protein = annual per capita protein consumption, $\mathrm{kg} / \mathrm{person} / \mathrm{yr}$

$\mathrm{F}_{\mathrm{NPR}}=$ fraction of nitrogen in protein, default $=0.16, \mathrm{~kg} \mathrm{~N} / \mathrm{yr}$

$\mathrm{F}_{\mathrm{NON}-\mathrm{CON}}=$ fraction for non-consumed protein added to the wastewater

$\mathrm{F}_{\text {IND-COM }}=$ factor for industrial and commercial co-discharged protein into the sewer system

$\mathrm{N}_{\text {SLUDGE }}=$ nitrogen removed with sludge $($ default $=0), \mathrm{kg} \mathrm{N} / \mathrm{yr}$

- $\quad \mathrm{N}_{2} \mathrm{O}$ emission from centralized wastewater treatment processes

$N_{2} O_{P L A N T S}=P . T_{P L A N T} \cdot F_{I N D-C O M} \cdot E F_{P L A N T}$

where,

$$
\begin{array}{ll}
\mathrm{N}_{2} \mathrm{O}_{\text {PLANTS }} & =\text { total } \mathrm{N}_{2} \mathrm{O} \text { emissions from plants in inventory year, } \mathrm{kg} \mathrm{N}_{2} \mathrm{O} / \mathrm{yr} \\
\mathrm{P} & =\text { human population }
\end{array}
$$




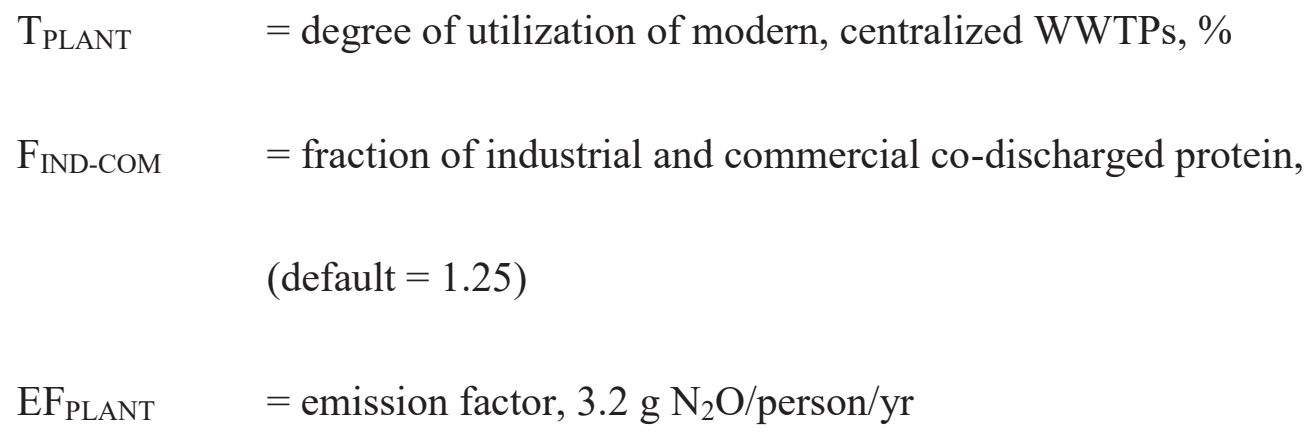

\section{Benefits of using IPCC guidelines}

The 2006 IPCC Guidelines for National Greenhouse Gas Inventories are valuable tools supporting to estimate and control GHG emissions. The guidelines for WWTPs emission could be found in chapter 6 of volume 5. The IPCC method shows out the relationship between different components and bases sorely on the annual organic matter and the amount of nitrogen. By adjusting these elements, the total emissions could be mitigated. Opportunities to mitigate methane emission are increasing portion of methane recovered and removed organic component. Nitrous oxide emission could be reduced when improving the portion of nitrogen removed in the sludge treatment process.

\section{Limitations of IPCC guidelines}

- Lack of information

WWTPs emit direct and indirect carbon dioxide due to microbial activities and energy consumption. Results found that a significant amount of carbon dioxide could be verified during biological wastewater treatment process, which excluded from IPCC guidelines (Kosse et al., 2018b). Methane is produced from closed sewer systems and those resulting from dissolved methane in the influent are not considered in the formulations, which can lead to underestimation. The relationship between organic and nitrate production is not indicated, which may limit the mitigating approach.

- Uncertainties with emission factors 
The emission factor is the most influential parameter that influences the total emissions (Brown et al., 2001). The IPCC provides default emission factors in most cases. However, these indicators are typically determined through field-scale monitoring. Thus, it is suggested to use the country-specific factors when available (Zhan et al., 2017). Estimation based on emission factors can be high uncertainty due to the lack of reliable information on the operation of the treatment process and the local environmental situation (Noyola et al., 2018). Also, the default emission factors have been used for years and need to be revised. Dissolved concentration in the influent wastewater, one of the important source of emission, was not considered in the guidelines result in need of a revision of correction factor.

\section{- Accuracy of data}

IPCC guidelines use some default data, which based on the experiment under specific conditions or particular circumstances. Applying the data representation for one specific case to others might affect the accuracy of the results. For example, the emission factor for $\mathrm{N}_{2} \mathrm{O}$ is currently based on a single study in which the WWTP was not designed for removal of nitrogen. For methane estimation, the formula mostly based on BOD while the other impact factors were excluded.

\section{b. Direct measure}

Most of the studies used this method to monitor the quantity of GHG emissions from each unit of the treatment processes. Gas flux were measured in aerated and non-aerated liquid surfaces. Gas samples were collected from multiple points to obtain the quantity of gas emitted. The number of sampling points based on the wastewater surface area and the dissolved oxygen variation in AAO process, while in SBR treatment process the sampling frequency was determined by the duration of each phase (Wang et al., 2011).

\section{Sample collection from the aerated area}


Polyethylene bag was used to collect gas samples emitted from aerated surfaces. The bag was fastened to inside of a support frame. The bag was collapsed and emptied of air. The frame was then immersed several inches in the water. Gas samples were withdrawn from the plastic bag to the aluminium foil plastic bags (Yan et al., 2014). When measuring the off-gas flow rate, a tracer gas is introduced into the chamber. The off-gas flow rate $E\left(\mu \mathrm{g} /\left(\mathrm{m}^{2} . \mathrm{hr}\right)\right)$ is calculated based on the mass balance of the tracer gas equation (7):

$$
E=(V / A) \rho(\Delta C / \Delta t)
$$

where,

$V$ is the volume of the flux hood $\left(\mathrm{m}^{3}\right) ; A$ is the enclosed surface area $\left(\mathrm{m}^{2}\right) ; \rho$ is the density of the gas $\left(\mathrm{mol} / \mathrm{m}^{3}\right)$; and $\Delta c / \Delta t$ is the gas concentration in the chamber.

\section{Sample collection from non-aerated area}

A floated flux chamber was used to measure the fluxes from non-aerated wastewater zones. A thermocouple probe was installed inside the flux chamber and floats made from tires are fastened to the flux hood's sides. The hood was kept stable to minimize chamber movement caused by surface turbulence. The sampling point was one metre from the bank of each processing unit or under the centre of the raised walkway across the unit tank. The gas within the chamber was transferred via a blower and a closed loop of the tube(Bao et al., 2016). The gas flux $F\left(\mu \mathrm{g} /\left(\mathrm{m}^{2} . h r\right)\right)$ was calculated by equation (8)

$$
F=(Q / A) \rho c
$$

where, 
$\rho$ is the density of the gas $\left(\mathrm{mol} / \mathrm{m}^{3}\right) ; c$ is the sample gas concentration $(\mathrm{mg} / \mathrm{L}) ; Q$ is the total diffuse air flow $\left(\mathrm{m}^{3} / \mathrm{min}\right) ; A$ is the total surface area $\left(\mathrm{m}^{2}\right)$

\section{GHGs sample analysis methods}

The samples were transported to the lab and analysed for GHG concentration after collected. A gas chromatograph equipped with a flame ionization detector (FID-GC) was used for methane measurement. The carbon dioxide concentration was determined by a thermal conductivity detector (TCD-GC) (Guérin et al., 2007). While nitrous oxide was analysed using a gas chromatograph with an electron capture detector (Hwang et al., 2016).

\section{Analysis of the direct measure method}

Static floating chamber method is widely used to evaluate the direct GHG emissions because of its convenience and low cost (Xiao et al., 2016). Static chamber with gas chromatography is widely applicable as this method has simple principle operation, cheap instrument, less time consuming and multisite observations (Wang et al., 2003). Gas chromatography has been widely used to quantify nitrous oxide and carbon dioxide concentrations in gas emissions from wastewater biological treatment process (Pascale et al., 2017). However, there are uncertainties in gas flux estimates using this method. They are less sensitive, low precision and poor accuracy when compare with other methods (Pascale et al., 2017). The poor accuracy comes from the experimental conditions such as outside temperature (Guérin et al., 2007), wind speed and rainfall intensity (Matthews et al., 2003), which is believed to increase the rate of GHG fluxes. The other factors that influence the accuracy are the limitation in the equipment and the methodology used to quantify emissions. The turbulence caused by the chamber's wall can affect the results (Xiao et al., 2016). The sensitive of the data is depending on the operating conditional, and the emission factors depend on load. For example, results at start-up and shut down are different with results in steady conditions. 
Effective methods should be a focus to minimising the variation between studies and solve the limitations of these estimation methods.

\subsection{Challenges in quantifying GHGs emissions from treatment processes}

Quantifying GHG emissions originating from WWTPs has its challenges. For example, carbon dioxide, which makes up the largest part of the total GHG from WWTPs, is usually neglected in reports (Schneider et al., 2015). Numerous papers focus on GHG emissions from the biological treatment process. However, very few studies were conducted to investigate the factors influencing overall emissions of carbon dioxide, nitrous oxide and methane. The results vary across the different studies, which vary in terms of influent concentration, process method and measurement technology. The conflicts between reports are essentially due to underestimation, especially for nitrous oxide the most significant GHG.

In AAO WWTPs, the oxic tank is the major unit of aeration zone that has the largest area of surface water and contributes the most GHG. Nitrous oxide and carbon dioxide emitted from the oxic zone in the bio-treatment tank of AAO WWTPs accounted for $97 \%$ and $96 \%$ of the total emissions, respectively. The proportion of methane may vary according to various reports, but the bulk of the methane was collected from the oxic tank. The aerated grit tank and anaerobic tank are also important units due to the quantity of methane and carbon dioxide emitted. However, there are conflicting results from the various studies, and for this reason, future research is needed.

In the SBR treatment process, most GHG emissions were produced in the feeding and aeration phases, while the settling phase and the decanting phase did not contribute to GHG emissions. The primary treatment units, which include the swirl grit tank and sewage distribution tank, generated small amounts of GHG emissions despite the high concentration of dissolved matter. One-third of the carbon dioxide in the SBR was related to the carbon 
dioxide produced when oxidising the organic matter; another third was related to power production while the remaining third represented the carbon dioxide equivalent due to the emission of methane and nitrous oxide (Real et al., 2017).

When analysing the quantity of GHG emissions from the AAO and SBR treatment processes, the results show that the latter produced more than the former. Carbon dioxide and methane emissions in WWTPs with SBR amounted to $347 \mathrm{~g} / \mathrm{m}^{3}$ and $0.5 \mathrm{~g} / \mathrm{m}^{3}$ of wastewater, respectively, and were approximately double that of the AAO WWTPs. The volume of nitrous oxide emitted from AAO was five times smaller than the SBR approximately $0.9 \mathrm{~g} / \mathrm{m}^{3}$ and $4.2 \mathrm{~g} / \mathrm{m}^{3}$, respectively. We can conclude that quantity of nitrous oxide emitted from a WWTP employing SBR for the biological treatment of municipal wastewater was larger than other bioreactor configurations (Rodriguez-Caballero et al., 2015). According to these results, aerated units contributed the major proportion of GHG emissions in both AAO and SBR WWTPs (Kyung et al., 2015). Non-aerated zones produced small amounts of GHGs for three important reasons. The first reason is due to the limited surface areas of the aerated zone. The oxic tank and the SBR tank are the largest of the treatment units. The second reason is that the substantial amounts of GHG emissions dissolved and accumulated in wastewater can be stripped off and released under aeration condition (Kyung et al., 2015). Third and finally, aeration process involves nitrification that produces nitrous oxide, as well as microbes that respire to generate carbon dioxide. Nitrous oxide was the major contributor towards to total GHG emissions during both two processes. During operation, aeration units consume the most energy and increase the quantity of carbon dioxide.

The concentration of DO is one of the most important parameters when controlling GHG emissions released from WWTPs. A low concentration of DO limits the growth of microorganism while high concentration could influence the denitrification process. Therefore, poorly dissolved oxygen leads to a reduction in indirect carbon dioxide emissions. 
Poorly dissolved oxygen could result in a large quantity of nitrous oxide occurring as a result of incomplete nitrification. In a few studies, the effect of aeration on emissions showed that strong aeration would lead to a higher volume of GHG emissions. Increasing aeration in both type of reactors would increase emissions. The aeration stripping rate of dissolved methane, carbon dioxide and nitrous oxide can affect the quantity of these gas emissions, as illustrated in Figure 4.

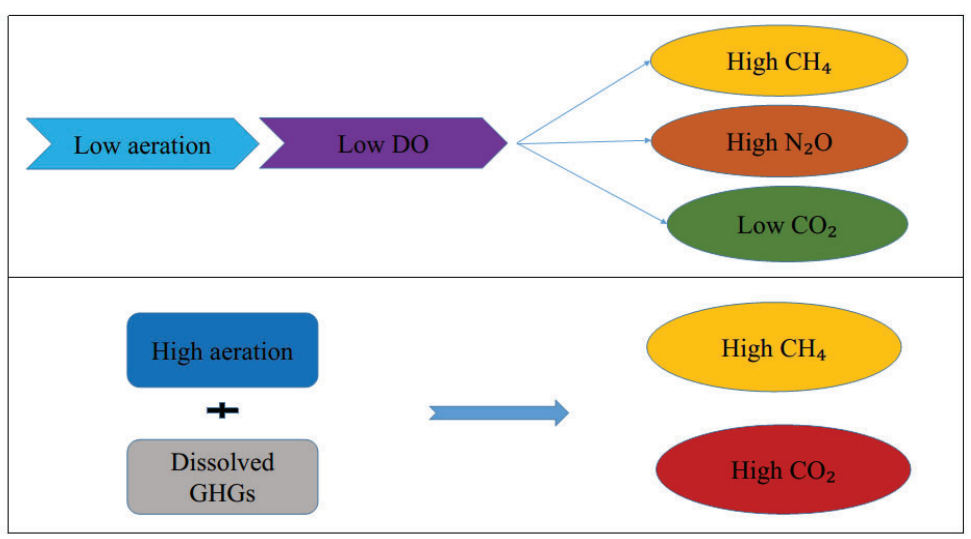

Figure 4. Influences of processes condition to GHG emissions

The impact of dissolved oxygen, aeration efficient and dissolved GHG have been researched and indicated in many studies. However, some of them reflected the different results and trend, as shown in Table 7.

Table 7. Reviewed studies on the influence of DO, aeration efficiency and dissolved gas on GHG emissions

\begin{tabular}{lcccc}
\hline GHG & Factors & Impact & Result & References \\
\hline $\mathrm{N}_{2} \mathrm{O}$ & DO & $\mathrm{N}_{2} \mathrm{O}$ increases when low & AGREE & (Wunderlin et al., 2012) \\
& DO concentrations & AGREE & (Aboobakar et al., 2013) \\
& & AGREE & (Jefferson et al., 2011)
\end{tabular}


AGREE (Peng et al., 2015)

AGREE (Wang et al., 2015)

AGREE (Massara et al., 2017)

NO (Rodriguez-Caballero et al., 2014)

Aeration rate High $\mathrm{N}_{2} \mathrm{O}$ at lower aeration AGREE (Hu et al., 2010)

rates

AGREE (Tumendelger et al., 2014)

Dissolved $\mathrm{N}_{2} \mathrm{O}$ High dissolved $\mathrm{N}_{2} \mathrm{O}$ cause

AGREE (Baresel et al., 2016)

high emission

AGREE (Pan et al., 2016)

NO (Masuda et al., 2018)

AGREE (Rodriguez-Caballero et al., 2015)

$\mathrm{CH}_{4} \quad$ Dissolved $\mathrm{CH}_{4}$ Correlate

AGREE (Rodriguez-Caballero et al., 2014)

AGREE (Noyola et al., 2018)

AGREE (Masuda et al., 2018)

DO Negative impact

AGREE (Rodriguez-Caballero et al., 2014)

$\mathrm{CO}_{2}$ Aeration Correlate

AGREE (Caniani et al., 2019)

AGREE (Bellandi et al., 2017)

Dissolved $\mathrm{CO}_{2}$ Correlate

AGREE (Kosse et al., 2018a)

The reviewed studies focused on major factors influencing the emission of one or two GHG, but the total quantity of GHG emissions from each treatment units was not indicated. One of the few papers that analysed two GHG emissions, Rodriguez-Caballero et al. (2014) evaluated methane and nitrous oxide emissions under different levels of DO and concentration of dissolved GHG. Carbon dioxide and nitrous oxide were measured from 
various parts of the WWTPs during the biological treatment process (Caniani et al., 2019). To the best of our knowledge, none of the existing studies indicates the source of emissions and analyses the impact of factors on overall GHG emissions. Controlling the oxygen and DO through aeration is the most effective method for controlling the GHG emissions. It will be beneficial to determine the optimal level of DO, aeration rate and dissolved GHG in the treatment processes.

\section{Future research for controlling strategies}

Different GHG emissions production pathways often occur simultaneously. Each pathway is regulated differently by environmental factors and thus needs to be analysed individually in term of the relative contribution to total GHG emission. Future research should focus on minimising uncertainties in estimating the emissions and determine the key parameters for GHGE emissions mitigation. These are explained in more detail below.

(I) Improve the accuracy of direct measurement methods

The limitations of existing measurement tools highlight the need for developing more precise methods. Recently Pascale et al. (2017) were the first to suggest using gas chromatograph equipped with a barrier ionization discharge detector. This tool can analyse carbon dioxide and nitrous oxide at the same time. However, the accuracy of this method should be tested in futher research.

(II) Develop the plant-wide model to simulate the WWTPs

Judging by the review of the literature, controlling the level of DO, aeration rate and dissolved GHG in the treatment process is important. Aeration makes the main contributor to the energy footprint of a WWTP because the energy associated with aeration may count for more than $50 \%$ of the total energy cost for a WWTP (Vilanova et al., 2017). The energy consumption of the WWTP can be reduced by reducing aeration. This will help mitigate 
carbon dioxide emissions but increase the volume of nitrous oxide, which has 300 times the GWP. Therefore, it is important to maintain a suitable level of DO concentration for economic reasons and to ensure that the treatment process remains stable. Due to the disadvantages of existing measurement methods, it is necessary to develop a model to evaluate the quantity of carbon dioxide, methane and nitrous oxide under various conditions of DO, aeration and dissolved gas in the biological treatment process. There is a need for further research into development of appropriate mitigation strategies to improve the effluent quality and reduce GHG emissions in wastewater treatment processes.

\section{Conclusion}

The AAO and SBR are popular treatment technologies in municipal WWTPs. However, they are also the most contribution to GHG emissions that are leading to global warming. The investigations confirmed that these technologies emitted high quantities of GHGs. The total emissions from a SBR wastewater treatment process are more significant than from an AAO process. An SBR process contributes maximum $1474 \mathrm{gCO}_{2}-\mathrm{eq} / \mathrm{m}^{3}$ while the highest quantity of emissions from an AAO process accounted to $437 \mathrm{gCO}_{2}-\mathrm{eq} / \mathrm{m}^{3}$. For better controlling of WWTPs, there is a need for developing effective quantification methods with low uncertainty and investigate the key impact factors inducing emissions and mitigation solution for GHG emissions.

\section{Acknowledgement}

This review research was supported by the Centre for Technology in Water and Wastewater (CTWW), University of Technology, Sydney (UTS, FEIT RIA NGO) and the Korea Institute of Energy Technology Evaluation and Planning (KETEP) and the Ministry of Trade, Industry \& Energy (MOTIE), Republic of Korea (No. 20183020141270).

\section{References}


Aboobakar, A., Cartmell, E., Stephenson, T., Jones, M., Vale, P., Dotro, G., 2013. Nitrous oxide emissions and dissolved oxygen profiling in a full-scale nitrifying activated sludge treatment plant. Water Res, 47(2), 524-534. http://doi.org/10.1016/j.watres.2012.10.0042013

Augenbraun, H., Matthews, E., Sarma, D., 1997. Global Methane Inventory. Retrieved from

Bao, Z., Sun, S., Sun, D., 2015. Characteristics of direct CO2 emissions in four full-scale wastewater treatment plants. Desalination and Water Treatment, 54(4-5), 1070-1079. 10.1080/19443994.2014.9403892015

Bao, Z., Sun, S., Sun, D., 2016. Assessment of greenhouse gas emission from A/O and SBR wastewater treatment plants in Beijing, China. International Biodeterioration \& Biodegradation, 108, 108-114. http://dx.doi.org/10.1016/j.ibiod.2015.11.0282016

Baresel, C., Andersson, S., Yang, J., Andersen, M. H., 2016. Comparison of nitrous oxide (N2O) emissions calculations at a Swedish wastewater treatment plant based on water concentrations versus off-gas concentrations. Advances in Climate Change Research, 7(3), 185-191. https://doi.org/10.1016/j.accre.2016.09.0012016

Bellandi, G., Mancini, I. M., Masi, S., Brienza, R., Panariello, S., Gori, R., Caniani, D., 2017. Monitoring the aeration efficiency and carbon footprint of a medium-sized WWTP: experimental results on oxidation tank and aerobic digester AU - Caivano, Marianna. Environmental Technology, 38(5), 629-638. 10.1080/09593330.2016.12051502017

Brown, L., Armstrong Brown, S., Jarvis, S. C., Syed, B., Goulding, K. W. T., Phillips, V. R., Sneath, R. W., Pain, B. F., 2001. An inventory of nitrous oxide emissions from agriculture in the UK using the IPCC methodology: emission estimate, uncertainty and sensitivity analysis. Atmospheric Environment, 35(8), 1439-1449. https://doi.org/10.1016/S1352-2310(00)0036172001

Campos, J., Valenzuela-Heredia, D., Pedrouso, A., Val del Río, Á., Belmonte, M., Mosquera-Corral, A.,2016. Greenhouse Gases Emissions from Wastewater Treatment Plants: Minimization, Treatment, and Prevention (Vol. 2016).

Caniani, D., Caivano, M., Pascale, R., Bianco, G., Mancini, I. M., Masi, S., Mazzone, G., Firouzian, M., Rosso, D., 2019. CO2 and N2O from water resource recovery facilities: Evaluation of emissions from biological treatment, settling, disinfection, and receiving water body. Science of The Total Environment, 648, 1130-1140. https://doi.org/10.1016/j.scitotenv.2018.08.1502019

Chai, C., Zhang, D., Yu, Y., Feng, Y., Wong, M., 2015. Carbon Footprint Analyses of Mainstream Wastewater Treatment Technologies under Different Sludge Treatment Scenarios in China. Water, 7(3), 918. 2015

Czepiel, P. M., Crill, P., Harriss, R.,1993. Methane emissions from municipal wastewater treatment processes (Vol. 27).

Daelman, M. R., De Baets, B., van Loosdrecht, M. C. M., Volcke, E. I., 2013. Influence of sampling strategies on the estimated nitrous oxide emission from wastewater treatment plants. Water research, 47(9), 3120-3130. 2013

Fang, F., Qiao, L., Cao, J., Li, Y., Xie, W., Sheng, G., Yu, H., 2016. Quantitative evaluation of A2O and reversed $\mathrm{A} 2 \mathrm{O}$ processes for biological municipal wastewater treatment using a projection pursuit method. Separation and Purification Technology, 166, 164-170. https://doi.org/10.1016/j.seppur.2016.04.0362016

Foley, J., de Haas, D., Yuan, Z., Lant, P., 2010. Nitrous oxide generation in full-scale biological nutrient removal wastewater treatment plants. Water Res, 44(3), 831-844. http://doi.org/10.1016/j.watres.2009.10.0332010

Frison, N., Chiumenti, A., Katsou, E., Malamis, S., Bolzonella, D., Fatone, F., 2015. Mitigating offgas emissions in the biological nitrogen removal via nitrite process treating anaerobic effluents. Journal of Cleaner Production, 93, 126-133. https://doi.org/10.1016/j.jclepro.2015.01.0172015

Garrido-Baserba, M., Molinos-Senante, M., Abelleira-Pereira, J. M., Fdez-Güelfo, L. A., Poch, M., Hernández-Sancho, F., 2015. Selecting sewage sludge treatment alternatives in modern wastewater treatment plants using environmental decision support systems. Journal of Cleaner Production, 107, 410-419. https://doi.org/10.1016/j.jclepro.2014.11.0212015 
Guérin, F., Abril, G., Serça, D., Delon, C., Richard, S., Delmas, R., Tremblay, A., Varfalvy, L., 2007. Gas transfer velocities of $\mathrm{CO} 2$ and $\mathrm{CH} 4$ in a tropical reservoir and its river downstream. Journal of Marine Systems, 66(1), 161-172. https://doi.org/10.1016/j.jmarsys.2006.03.0192007

Hu, Z., Zhang, J., Li, S., Xie, H., Wang, J., Zhang, T., Li, Y., Zhang, H., 2010. Effect of aeration rate on the emission of $\mathrm{N} 2 \mathrm{O}$ in anoxic-aerobic sequencing batch reactors (A/O SBRs). Journal of Bioscience and Bioengineering, 109(5), 487-491. https://doi.org/10.1016/j.jbiosc.2009.11.0012010

Hwang, K., Bang, C., Zoh, K., 2016. Characteristics of methane and nitrous oxide emissions from the wastewater treatment plant. Bioresource Technology, 214, 881-884. https://doi.org/10.1016/j.biortech.2016.05.0472016

IPCC. 2006. 2006 IPCC Guidelines for National Greenhouse Gas Inventories, Prepared by the National Greenhouse Gas Inventories Programme, Egglesto H.S., Buendia L., Miwa K., Ngara T. and Tanabe K. (eds). Published: IGES, Japan. 2006

IPCC. 2007. Climate Change 2007: Synthesis Report. Contribution of Working Group I, II and III to the Fourth Assessment Report of the Intergovernmental Panel on Climate Change [Core Writing team, Pachauri, R.K and Reisinger, A. (eds.)]. IPCC, Geneva, Switzerland, 104 pp. 2007

IPCC. 2014a. Annex II: Glossary [Mach, K.J., S. Planton and C. von Stechow (eds.)]. In: Climate Change 2014: Synthesis Report. Contribution of Working Groups I, II and III to the Fifth Assessment Report of the Intergovernmental Panel on Climate Change [Core writing Team, R.K. Pachauri and L.A. Meyer (eds.)]. . IPCC, Geneva, Switzerland, 117-130. 2014a

IPCC. 2014b. Climate Change 2014: Synthesis Report. Contribution of Working Group I, II, III to the Fifth Assessment Report of the Intergovernmental Panel on Climate Change [Core Writing Team, R.K. Pachauri and L.A. Meyer (eds)]. IPCC, Geneva, Switzerland, 151 pp. 2014b

Janssens-Maenhout, G., Crippa, M., Guizzardi, D., Muntean, M., Schaaf, E., Dentener, F., Bergamaschi, P., Pagliari, V., Olivier, J. G. J., Peters, J. A. H. W., van Aardenne, J. A., Monni, S., Doering, U., Petrescu, A. M. R., 2017a. EDGARv4.3.2 Global Atlas of the three major Greenhouse Gas Emissions for the period 1970-2012 Earth Syst. Sci. Data Discuss.

Janssens-Maenhout, G., Crippa, M., Guizzardi, D., Muntean, M., Schaaf, E., Olivier, J. G. J., Peters, J. A. H. W., Schure, K. M., 2017b. Fossil CO2 and GHG emissions of all world countries EUR 28766 EN,Publications Office of the European Union Luxembourg.

Jefferson, B., Jones, M., Vale, P., Cartmell, E., Stephenson, T., 2011. A review of the impact and potential of intermittent aeration on continuous flow nitrifying activated sludge AU - Dotro, Gabriela. Environmental Technology, 32(15), 1685-1697. $10.1080 / 09593330.2011 .5977832011$

Kampschreur, M. J., Tan, N. C. G., Kleerebezem, R., Picioreanu, C., Jetten, M. S. M., Loosdrecht, M. C. M. V., 2008. Effect of Dynamic Process Conditions on Nitrogen Oxides Emission from a Nitrifying Culture. Environmental Science \& Technology, 42(2), 429-435. $10.1021 / \mathrm{es} 071667 \mathrm{p} 2008$

Kampschreur, M. J., Temmink, H., Kleerebezem, R., Jetten, M. S. M., van Loosdrecht, M. C. M., 2009. Nitrous oxide emission during wastewater treatment. Water research, 43(17), 4093 4103. http://dx.doi.org/10.1016/j.watres.2009.03.0012009

Kosonen, H., Heinonen, M., Mikola, A., Haimi, H., Mulas, M., Corona, F., Vahala, R., 2016. Nitrous Oxide Production at a Fully Covered Wastewater Treatment Plant: Results of a Long-Term Online Monitoring Campaign. Environmental Science \& Technology, 50(11), 5547-5554. http://doi.org/10.1021/acs.est.5b044662016

Kosse, P., Kleeberg, T., Lübken, M., Matschullat, J., Wichern, M., 2018a. Quantifying direct carbon dioxide emissions from wastewater treatment units by nondispersive infrared sensor (NDIR) A pilot study. Science of The Total Environment, 633, 140-144. https://doi.org/10.1016/j.scitotenv.2018.03.1742018a

Kosse, P., Kleeberg, T., Lübken, M., Matschullat, J., Wichern, M.,2018b. Quantifying direct carbon dioxide emissions from wastewater treatment units by nondispersive infrared sensor (NDIR) A pilot study (Vol. 633). 
Koutsou, O. P., Gatidou, G., Stasinakis, A. S., 2018. Domestic wastewater management in Greece: Greenhouse gas emissions estimation at country scale. Journal of Cleaner Production, 188, 851-859. https://doi.org/10.1016/j.jclepro.2018.04.0392018

Kyung, D., Kim, M., Chang, J., Lee, W., 2015. Estimation of greenhouse gas emissions from a hybrid wastewater treatment plant. Journal of Cleaner Production, 95(Supplement C), 117-123. https://doi.org/10.1016/j.jclepro.2015.02.0322015

Law, Y., Jacobsen, G. E., Smith, A. M., Yuan, Z., Lant, P., 2013. Fossil organic carbon in wastewater and its fate in treatment plants. Water research, 47(14), 5270-5281. https://doi.org/10.1016/j.watres.2013.06.0022013

Law, Y., Lant, P., Yuan, Z., 2011. The effect of $\mathrm{pH}$ on N2O production under aerobic conditions in a partial nitritation system. Water research, 45(18), 5934-5944. https://doi.org/10.1016/j.watres.2011.08.0552011

Law, Y., Ye, L., Pan, Y., Yuan, Z., 2012. Nitrous oxide emissions from wastewater treatment processes. Philosophical Transactions of the Royal Society B: Biological Sciences, 367(1593), 1265-1277. http://doi.org/10.1098/rstb.2011.03172012

Liu, Y., Cheng, X., Lun, X., Sun, D., 2014. CH4 emission and conversion from A2O and SBR processes in full-scale wastewater treatment plants. Journal of Environmental Sciences, 26(1), 224-230. http://dx.doi.org/10.1016/S1001-0742(13)60401-52014

Mannina, G., Ekama, G., Caniani, D., Cosenza, A., Esposito, G., Gori, R., Garrido-Baserba, M., Rosso, D., Olsson, G., 2016. Greenhouse gases from wastewater treatment - A review of modelling tools. Science of The Total Environment, 551-552(Supplement C), 254-270. https://doi.org/10.1016/j.scitotenv.2016.01.1632016

Marques, R., Rodriguez-Caballero, A., Oehmen, A., Pijuan, M., 2016. Assessment of online monitoring strategies for measuring $\mathrm{N} 2 \mathrm{O}$ emissions from full-scale wastewater treatment systems. Water research, 99, 171-179. https://doi.org/10.1016/j.watres.2016.04.0522016

Massara, T. M., Malamis, S., Guisasola, A., Baeza, J. A., Noutsopoulos, C., Katsou, E., 2017. A review on nitrous oxide $(\mathrm{N} 2 \mathrm{O})$ emissions during biological nutrient removal from municipal wastewater and sludge reject water. Science of The Total Environment, 596-597, 106-123. https://doi.org/10.1016/j.scitotenv.2017.03.1912017

Masuda, S., Sano, I., Hojo, T., Li, Y., Nishimura, O., 2018. The comparison of greenhouse gas emissions in sewage treatment plants with different treatment processes. Chemosphere, 193, 581-590. https://doi.org/10.1016/j.chemosphere.2017.11.0182018

Matthews, C. J. D., St. Louis, V. L., Hesslein, R. H., 2003. Comparison of three techniques used to measure diffusive gas exchange from sheltered aquatic surfaces. Environmental Science and Technology, 37(4), 772-780. http://doi.org/10.1021/es02058382003

Mulkerrins, D., Jordan, C., McMahon, S., Colleran, E., 2000. Evaluation of the parameters affecting nitrogen and phosphorus removal in anaerobic/anoxic/oxic $(\mathrm{A} / \mathrm{A} / \mathrm{O})$ biological nutrient removal systems. Journal of Chemical Technology and Biotechnology, 75(4), 261-268. 10.1002/(SICI) 1097-4660(200004)75:4<261::AID-JCTB213>3.0.CO;2-X2000

Noyola, A., Paredes, M. G., Güereca, L. P., Molina, L. T., Zavala, M., 2018. Methane correction factors for estimating emissions from aerobic wastewater treatment facilities based on field data in Mexico and on literature review. Science of The Total Environment, 639, 84-91. https://doi.org/10.1016/j.scitotenv.2018.05.1112018

Oshita, K., Okumura, T., Takaoka, M., Fujimori, T., Appels, L., Dewil, R., 2014. Methane and nitrous oxide emissions following anaerobic digestion of sludge in Japanese sewage treatment facilities. Bioresource Technology, 171, 175-181. https://doi.org/10.1016/j.biortech.2014.08.0812014

Pan, Y., van den Akker, B., Ye, L., Ni, B. J., Watts, S., Reid, K., Yuan, Z., 2016. Unravelling the spatial variation of nitrous oxide emissions from a step-feed plug-flow full scale wastewater treatment plant. Scientific Reports, 6, 20792. 10.1038/srep20792

https://www.nature.com/articles/srep20792\#supplementary-information2016

Parravicini, V., Svardal, K., Krampe, J., 2016. Greenhouse Gas Emissions from Wastewater Treatment Plants. Energy Procedia, 97, 246-253. http://dx.doi.org/10.1016/j.egypro.2016.10.0672016 
Pascale, R., Caivano, M., Buchicchio, A., Mancini, I. M., Bianco, G., Caniani, D., 2017. Validation of an analytical method for simultaneous high-precision measurements of greenhouse gas emissions from wastewater treatment plants using a gas chromatography-barrier discharge detector system. Journal of Chromatography A, 1480, 62-69. https://doi.org/10.1016/j.chroma.2016.11.0242017

Peng, L., Ni, B. J., Ye, L., Yuan, Z., 2015. The combined effect of dissolved oxygen and nitrite on $\mathrm{N} 2 \mathrm{O}$ production by ammonia oxidizing bacteria in an enriched nitrifying sludge. Water research, 73, 29-36. https://doi.org/10.1016/j.watres.2015.01.0212015

Polruang, S., Sirivithayapakorn, S., Prateep N. T., R., 2018. A comparative life cycle assessment of municipal wastewater treatment plants in Thailand under variable power schemes and effluent management programs. Journal of Cleaner Production, 172, 635-648. https://doi.org/10.1016/j.jclepro.2017.10.1832018

Préndez, M., Lara-González, S., 2008. Application of strategies for sanitation management in wastewater treatment plants in order to control/reduce greenhouse gas emissions. Journal of Environmental Management, 88(4), 658-664. http://doi.org/10.1016/j.jenvman.2007.03.0412008

Puig, S., 2008. Operation and control of SBR processes for enhanced biological nutrient removal from wastewater. PhD Thesis, Universidade de Girona, Spain.

Real, A., Garcia-Martinez, A. M., Pidre, J. R., Coello, M. D., Aragon, C. A., 2017. Environmental assessment of two small scale wastewater treatment systems: SBR vs CAS. Water Practice and Technology, 12(3), 549-556. http://doi.org/10.2166/wpt.2017.0662017

Ren, Y., Wang, J., Xu, L., Liu, C., Zong, R., Yu, J., Liang, S., 2015. Direct emissions of N2O, CO 2, and $\mathrm{CH} 4$ from $\mathrm{A} / \mathrm{A} / \mathrm{O}$ bioreactor systems: impact of influent $\mathrm{C} / \mathrm{N}$ ratio. Environ Sci Pollut Res Int, 22(11), 8163-8173. http://doi.org/10.1007/s11356-015-4408-82015

Ren, Y. G., Wang, J. H., Li, H. F., Zhang, J., Qi, P. Y., Hu, Z., 2013. Nitrous oxide and methane emissions from different treatment processes in full-scale municipal wastewater treatment plants. Environmental Technology, 34(21), 2917-2927. 10.1080/095933330.2012.6967172013

Rodriguez-Caballero, A., Aymerich, I., Marques, R., Poch, M., Pijuan, M., 2015. Minimizing N2O emissions and carbon footprint on a full-scale activated sludge sequencing batch reactor. Water research, 71, 1-10. https://doi.org/10.1016/j.watres.2014.12.0322015

Rodriguez-Caballero, A., Aymerich, I., Poch, M., Pijuan, M., 2014. Evaluation of process conditions triggering emissions of green-house gases from a biological wastewater treatment system. Science of The Total Environment, 493, 384-391. https://doi.org/10.1016/j.scitotenv.2014.06.0152014

Rodriguez-Caballero, A., Pijuan, M., 2013. N2O and NO emissions from a partial nitrification sequencing batch reactor: Exploring dynamics, sources and minimization mechanisms. Water research, 47(9), 3131-3140. https://doi.org/10.1016/j.watres.2013.03.0192013

Rosso, D., Stenstrom, M. K., 2008. The carbon-sequestration potential of municipal wastewater treatment. Chemosphere, 70(8), 1468-1475. http://dx.doi.org/10.1016/j.chemosphere.2007.08.0572008

Schneider, A. G., Townsend-Small, A., Rosso, D., 2015. Impact of direct greenhouse gas emissions on the carbon footprint of water reclamation processes employing nitrification-denitrification. Science of The Total Environment, 505(Supplement C), 1166-1173. https://doi.org/10.1016/j.scitotenv.2014.10.0602015

Singh, M., Srivastava, R. K., 2011. Sequencing batch reactor technology for biological wastewater treatment: a review. Asia-Pacific Journal of Chemical Engineering, 6(1), 3-13. doi:10.1002/apj.4902011

Soda, S., Arai, T., Inoue, D., Ishigaki, T., Ike, M., Yamada, M., 2013. Statistical analysis of global warming potential, eutrophication potential, and sludge production of wastewater treatment plants in Japan. Journal of Sustainable Energy \& Environment, 4(1), 33-40. 2013

Spinelli, M., Eusebi, A. L., Vasilaki, V., Katsou, E., Frison, N., Cingolani, D., Fatone, F., 2018. Critical analyses of nitrous oxide emissions in a full scale activated sludge system treating low carbon-to-nitrogen ratio wastewater. Journal of Cleaner Production, 190, 517-524. https://doi.org/10.1016/j.jclepro.2018.04.1782018 